\title{
Diabetes Mellitus and Xerostomia: An Obnoxious Co-Occurrence
}

\author{
Miss. Chaithra Indumathi Vasudev ${ }^{1}$, Dr. Roopashri Rajesh Kashyap M.D.S. ${ }^{2}$, Dr.Raghavendra \\ Kini M.D.S ${ }^{3}$, Dr. Prasanna Kumar Rao M.D.S ${ }^{4}$, Dr. Vijayendranath Nayak $\mathbf{S}^{5^{*}}$ \\ ${ }^{1}$ Undergraduate student, A.J. Institute of Dental Sciences, Mangalore- 575004, Karnataka, India. \\ ${ }^{2}$ Reader, Dept. of Oral Medicine and Radiology, A.J. Institute of Dental Sciences, Mangalore-575004, \\ Karnataka, India \\ ${ }^{3}$ Professor, Dept. of Oral Medicine and Radiology, A.J. Institute of Dental Sciences, Mangalore- 575004, \\ Karnataka, India \\ ${ }^{4}$ Professor, Dept. of Oral Medicine and Radiology, A.J. Institute of Dental Sciences, Mangalore- 575004, \\ Karnataka, India \\ ${ }^{5}$ Post Graduate, Dept. of Oral Medicine and Radiology, A.J. Institute of Dental Sciences, Mangalore- 575004, \\ Karnataka, India \\ *Corresponding Author: Dr. Vijayendranath Nayak S, Post Graduate, Dept. of Oral Medicine and \\ Radiology, A.J. Institute of Dental Sciences, Mangalore- 575004, Karnataka, India. Email: drnayakomr \\ @ gmail.com
}

\begin{abstract}
Diabetes mellitus is a multisystemic disease characterized by hyperglycemia resulting from defects in insulin secretion, insulin action or both. Xerostomia or dry mouth is a frequent complication seen in diabetic patients. Here we report a case of 53-year-old female presented with dry mouth secondary to diabetesmellitus.
\end{abstract}

\section{INTRODUCTION}

Diabetes mellitus is a multisystemic disorder either due to decreased insulin production or impaired insulin utilization. Because it is a multisystemic disease it also manifestations in the oral cavity like dryness, cracking, peeling and atrophic lip with smooth, depapillated, erythematous, fissured or cracked tongue. Diabetic patients also predispose to candidiasis and high rate of caries.

\section{CASE History}

A 53-year-old female patient reported with a chief complaint of thedry mouthof one-year duration. The patient felt thedryness of mouth throughout the day and had difficulty in speech \&swallowing. The patient frequently sipped water to relieve dryness. The patientwas a known diabetic and hypertensivefor 9 years and was under insulin therapy since 5years. General physical examination and extraoral examination did not reveal any abnormalities. On intraoral examination, the lips, floor of the mouth and buccal mucosa appeared dry. The mouth mirror was highly sticking to the buccal mucosa suggestive of reduced salivation. (Figure1) the tongue appeared dry, pebbly and
cracked.(Figure 2) The patient was advised to sip water frequently, reduce intake of sugary food, maintain proper dental hygiene and use salivary substitute like xerostom spray. ${ }^{\circledR}$

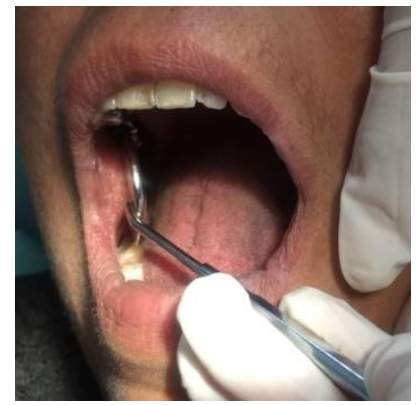

Figure1. The mouth mirror sticking to the buccal mucosa

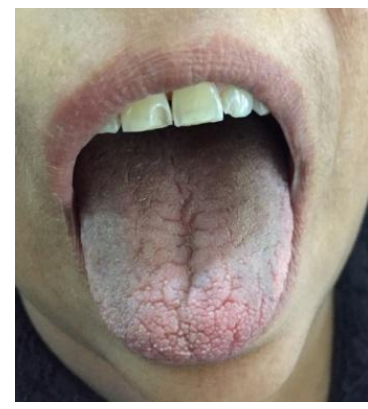

Figure2. The tongue appeared dry and cracked 


\section{DISCUSSION}

Diabetes mellitus is a group of metabolic diseases characterized by hyperglycemia resulting from defects in insulin secretion, insulin action or both. ${ }^{1}$ It has become a global epidemic complications are usually proportional to the degree and duration of hyperglycemia. ${ }^{2}$ The chronic hyperglycemia of diabetes is associated with dysfunction and failures of various organs like eyes, kidneys, nerves, heart and blood vessels. ${ }^{1}$

The previous studies have reported theincidence of xerostomia in $40 \%-80 \%$ of patients suffering from diabetes. ${ }^{3}$ The decrease in salivary flow in diabetic patients is caused by multiple factors like the changes in the parenchyma of the salivary gland, glycosuria or polyuria and diabetic complications such as neuropathy, angiopathy, and adecrease in the activity of enzymes located in the salivary glands. Reduced salivary flow is quite annoying for the patients as it disturbs their daily activities and can cause difficulties in tasting, chewing, swallowing and speaking. It can also increase the chance of developing dental caries, demineralization of teeth, tooth sensitivity and opportunistic infections like candidiasis.

The general approach to treating patients with xerostomia is directed at palliative treatment for the relief of symptoms and prevention of oral complications. ${ }^{4}$ Meticulous oral hygiene plays a key role in managing dry mouth patients. Patients will require more frequent dental visits. ${ }^{5}$ The patients should be advised to avoid cariogenic foods and beverages containing alcohol and caffeine and they should be motivated to sip water regularly to keep the mouth hydrated. If necessary they can be prescribed salivary stimulants or salivary substitutes.

\section{Conclusion}

Dry mouth is a frequent complication seen in diabetic patients. Dental practitioners should be aware of the complications seen in diabetic patients as they play a key role in managing oral manifestations of diabetes mellitus.

\section{REFERENCES}

[1] American Diabetes Association. Diagnosis and classification of diabetes mellitus. Diabetes care. 2014 Jan 1;37(Supplement 1):S81-90.

[2] Mauri-Obradors E, Estrugo-Devesa A, JanéSalas E, Viñas M, LópezLópez J. Oral manifestations of Diabetes Mellitus. A systematic review. Med Oral Patol Oral Cir Bucal. 2017 Sep 1;22 (5):e586-94.

[3] Lalla RV, D'AMBROSIO JA. Dental management considerations for the patient with diabetes mellitus. The Journal of the American Dental Association. 2001 Oct 31;132(10):142532.

[4] Burket LW, Greenberg MS, Glick M. Burket's oral medicine: diagnosis \& treatment. PMPHUSA; 2003.

[5] Venables PJ. Sjögren's syndrome. Best Practice \& Research Clinical Rheumatology. 2004 Jun 30;18(3):313-29.

Citation: Miss. Chaithra Indumathi Vasudev, Dr. Roopashri Rajesh Kashyap, Dr.Raghavendra Kini, Dr. Prasanna Kumar Rao, Dr. Vijayendranath Nayak S. Diabetes Mellitus and Xerostomia: An Obnoxious CoOccurrence. ARC Journal of Dental science. 2018; 3(1): 1-2. doi:dx.doi.org/ 10.20431/2456-0030. 0301001.

Copyright: () 2018 Authors. This is an open-access article distributed under the terms of the Creative Commons Attribution License, which permits unrestricted use, distribution, and reproduction in any medium, provided the original author and source are credited. 